The Journal of Vitaminology 6, 151-154 (1960)

\title{
STUDIES ON LIPEMIA-CLEARING FACTOR IN RELATION TO PYRIDOXAL PHOSPHATE
}

\author{
KOZO YAMADA, HUMIO KUZUYA AND MASATOSHI NODA \\ Third Department of Internal Medicine, Nagoya University School of \\ Medicine, Showa, Nagoya \\ (Received February 15, 1960)
}

Many research workers have shown that lipemia-clearing activity which is detectable in postheparin plasma is due to lipoprotein lipase. Engelberg (1) assumed heparin to be the coenzyme. In this paper, the enzymatical charactors of the lipemia-clearing factor purified by Nikkilä's method is reported.

\section{EXPERIMENTAL}

\section{Methods}

Purification of Clearing Factor of Postheparin Human Plasma-Human blood was collected 10 minutes after heparin injection $(0.5 \mathrm{mg}$ per $\mathrm{kg}$ body weight) and the plasma was isolated. This postheparin human plasma was purified by Nikkilä's method (2).

Determination of Clearing Activity - As the substrate for the active enzyme the following emulsion was used: $10 \mathrm{ml}$ of $M / 15$ phosphate buffer $(\mathrm{pH}$ 7.4) ; 1 drop of $20 \%$ sesame-oil emulsion, and $2.5 \mathrm{ml}$ of inactive human plasma. This substrate was used after incubation at $37^{\circ}$ for 60 minutes. Inactive human plasma was used after testing its inactivity. To $2 \mathrm{ml}$ of this substrate was added $1 \mathrm{ml}$ of active enzyme solution. This reaction mixture was incubated at $37^{\circ}$ for 120 minutes. The clearing activity was measured by reduction in turbidity of this mixture $(650 \mathrm{~m} \mu)$. Protein concentration was determined by biuret reaction.

\section{RESULTS}

The absorption spectrum of the purified solution was almost similar to that of pyridoxal phosphate as shown in Fig. 1. The purified solution was then brought to its isoelectric point ( $\mathrm{pH} 5-4.8)$. $\quad 0.05 M$ sodium citrate was added to the precipitate after centrifugation, and the $\mathrm{pH}$ was brought back to 7.8. The precipitate thus formed is dissolved and dialyzed against distilled water at $0^{\circ}$ after adjusting the $\mathrm{pH}$ to 5.4. The absorption maximum of the dialyz- 


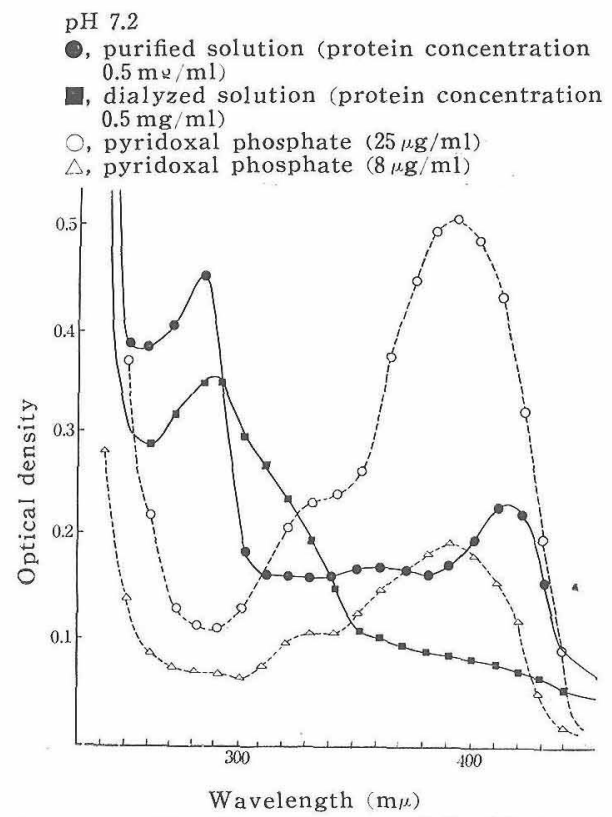

FIG. 1 Absorbtion-Spectra of Purified and Dialyzed Clearing Factor ed solution which had been observed at $410-420 \mathrm{~m} \mu$ in the purified solution prior to dialysis as shown inFig. 1, was disappeared.

The clearing activity of two kinds of the purified solutions, one was the dialyzed solution, and the other was the dialyzed solution added

․, $M / 15$ phosphate buffer $x$, Ringer's buffer

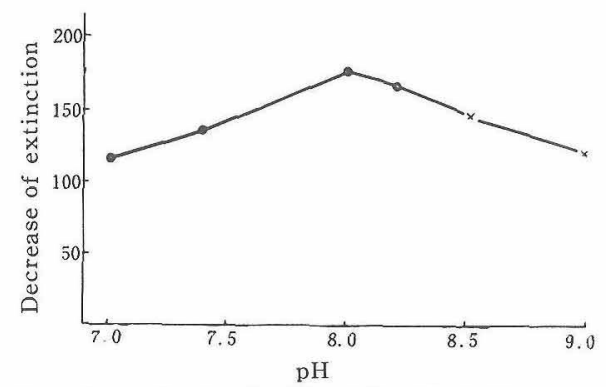

Fig. 2 Optimal pH of Purified Clearing

TABLE I

Purification and Dialysis of Human Plasma

\begin{tabular}{|c|c|c|c|c|}
\hline & & $\begin{array}{l}\text { Protein } \\
\text { concentration }\end{array}$ & $\begin{array}{l}\text { Clearing } \\
\text { activity }\end{array}$ & $\begin{array}{l}\text { Clearing activity } \\
\text { per } m g \text { protein }\end{array}$ \\
\hline \multirow{5}{*}{$\begin{array}{l}A \\
B \\
C \\
D\end{array}$} & & $m g / m l$ & & \\
\hline & Postheparin human plasma & 78 & 0.264 & 0.003 \\
\hline & Purified solution before dialysis & 2 & 0.174 & 0.087 \\
\hline & Purified solution after dialysis & 0.5 & 0 & 0 \\
\hline & $\begin{array}{l}\text { Purified solution after dialysis + } \\
\text { pyridoxal phosphate, } 10 \mu \mathrm{g} / \mathrm{ml}\end{array}$ & 0.5 & 0.059 & 0.118 \\
\hline E & $\begin{array}{l}\text { Purified solution after dialysis } \\
\text { heparin, } 0.3 \mu \mathrm{g} \mathrm{ml}\end{array}$ & 0.5 & -0.018 & \\
\hline
\end{tabular}

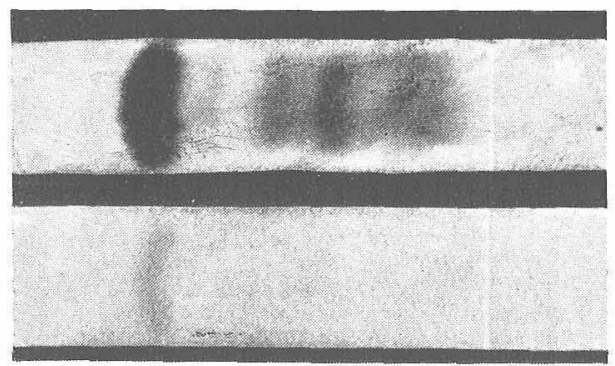

Fic. 3 Paper Electrophoresis of Purified Clearing Factor

Upper, human plasma

Lower, purified clearing factor with pyridoxal phosphate (final concentration, $10 \mathrm{mg}$ per $\mathrm{ml}$ ), was compared, and it was found that the clearing activity was reduced by dialysis but it recovered markedly after adding pyridoxal phosphate (Table I).

The optimal $\mathrm{pH}$ of the purified enzyme activity was determined using phosphate buffer $(M / 15)$ and Ringer's buffer $(M / 15)$, and it was found to be pH 8.0 as shown in Fig. 2 . 
Paper electrophoresis of the purified solution showed that the enzyme was located in albumin fraction (Fig. 3).

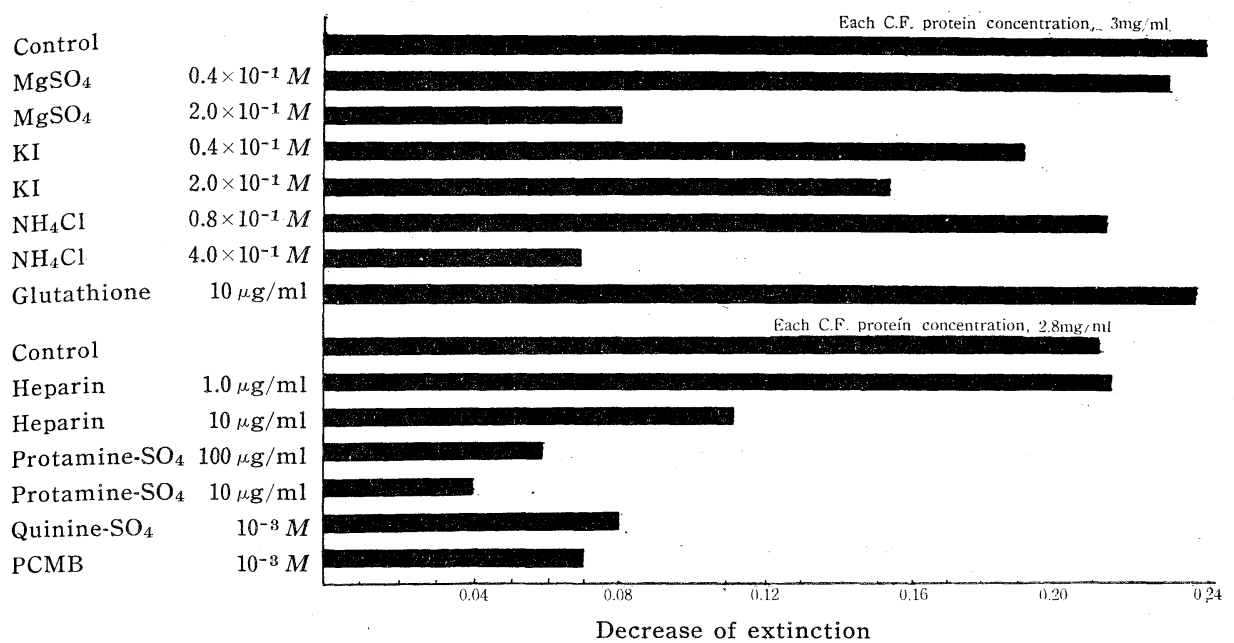

FIG. 4 Inhibition of C.F. (purified)

In vitro inhibition of the enzyme activity by various drugs were then studied. Protamine sulfate, quinine sulfate, $p$-chloromercuribenzoate (PCMB), heparin and some inorganic substances inhibited the enzyme activity as shown in Fig. 4. However, inorgnic substances inhibited only at high concentrations. Reduced gultathione failed to inhibit.

\section{DISCUSSION}

Skorepa et al. (3) reported that heparin might be contained in lipoprotein lipase but not in esterase. Engelberg (1) also assumed heparin to be a coenzyme of clearing factor. Robinson et al. (4) noticed the stability of the enzyme system in haparinized plasma to be markedly reduced in the presence of protamine. But Robinson et al. (5) suggested in another report that some component necessary for the activity of the lipolytic system induced in blood by the injection of heparin is normally located on the inner surface of the vascular wall and is released from these into the blood stream. Spitzer et al. (6) reported the clearing factor to be present in albumin fraction, but Eiber et al. (7) recognized in albumin fraction only a trace of the $S^{35}$ of the heparin injected. The authors also recognized the enzyme to be present in the albumin fraction electrophoretically. From this observation that the lipolytic activity reduced by dialysis was recovered by pyridoxal phosphate, it is concluded that one component necessary for the activity of the lipolytic system is pyridoxal phosphate rather than heparin. 


\section{SUMMARY}

1. In the absorption spectrum of the purified clearing factor two absorption maxima were recognized, i.e., $270-280$ and $410-420 \mathrm{~m} \mu$.

2. Lipolytic activity reduced by dialysis was recovered by pyridoxal phosphate, but not by heparin. It is probable that one component necessary for the activity of the lipolytic system is pyridoxal phosphate.

3. Optimal $\mathrm{pH}$ of the enzyme activity was 8.0.

4. The enzyme was shown to exist in albumin fraction electrophoretically.

5. The enzyme was inhibited by protamine sulfate, quinine sulfate, pCMB and heparin, but not by glutathione.

\section{REFERENCES}

1. Engelberg, H., Proc. Soc. Exptl. Biol. Med. 90, 489 (1958).

2. Nikkilä, E. A., Bioch. Biophys. Acta 27, 612 (1958).

3. Skorepa, J., and Novak, S., Nature 182, 117 (1958).

4. Robinson, D.S., Jeffries, G. H., and French, J.E., Quart. J. Exptl. Physiol. 39, 165 (1964).

5. Robinson, D. S., and French, J. E., ibid. 42, 151 (1957).

6. Spitzer, J. J., Am. J. Physiol. 171, 492 (1952).

7. Eiber, H. B., and Danishefsky, I., Proc. Soc. Exptl. Biol. Med. 102, 18 (1959). 